biological control of insect pests, and with medical entomology. General botany and plant diseases of the Pacific region constituted the two subsections of section 6 . Section 7 consisted of public health and nutrition, and was divided into subsections dealing with the geography and epidemiology of the communicable diseases of the Pacific region, with health hazards arising from transport, occupation and agricultural practices, with nutritional problems and finally with education in matters of health. Section 8 dealt with the characteristics, utilization and conservation of the soils in the countries of the Pacific.

All who are in any way interested in the manifold scientific problems of the Pacific owe a debt of gratitude to the National Research Council of the United States and to all who pressed, against considerable and not unnatural opposition, for the holding of this Congress. Thero must be many of the foreign delegates who now feel, with the writer, that this meeting, attended by so many races and nationalities united in the prosecution of disin. terested scientific research, will bo during the darkness which looms ahead both a memory of a happier past and a foretaste of a more enlightened future. The Congress broke up in the expectation of a seventh Congress to be held in the Philippines in 1943. That the future courso of world history makes this possible may well be the wish of every civilized human being.

\title{
LOWER PERMIAN INSECTS OF KANSAS
}

F. M. CARPENTER has recently discussed 1 . numerous specimens of fossil insects obtained in 1935 from the Elmo limestono (Kangas), of Lowor Pormian ago (Proc. Amer. Acad. Arts and Sci., 73, $29-70$; 1939). More than 8,000 specimens from this formation are now in the collections of the Harvard Museum of Comparative Zoology.

The results of the 1935 collection exceed all others in the number of complete, or nearly completo, specimens that wero disclosed. Some of the most interesting fossils obtained aro members of the group which Tillyard named the Protohymenoptera, and now regarded as belonging to the Megasecoptera. Thus, in Permohymen, the male genitalia aro woll preserved and aro seen to bo composed of paired penes with two-segmented claspers which are ovidently homologous with tho styli of may-flies. Regarding Asthenohymen dunbari, 32 specimens were found, and, of these, four present enough of the body structure to allow, for the first time, a complote reconstruction of the insect to be made and the differences between the fore and hind wings to bo ascertained. In one example the ovipositor is woll preserved.

The Protodonata that wero collected on the 1935 expedition proved to bo unusually interesting. In the first place tho discovory of Meganeuropsis permiana gen. et. sp. nov. from the Permian of Elmo constitutes the first example of a Meganeurine occurring in the
New World and also in rocks of Permian date. Dr. Carpenter discusses the affinities of the family Meganeuridx, and does not accept Martynov's con. tention that they should be placed in the order Odonata as true dragonfies: he concludes that there is no justification for thoir separation from the Protodonata until it is proved that the Meganouridx had a phylogenotic origin different from that of the other families of that order.

The author then passes on to deal with the Homoptera. Altogether twenty-six specimens belonging to this group wore collocted. While none of the species is new, the material adds to knowledgo of the body structure and the hind wings of the Homoptera. In Permoscytina kansasensis Till. tho single specimen obtained during 1935 shows a long process extending straight back from the end of the abdomen : being $9 \mathrm{~mm}$. long, it exceeds the length of the combined thorax and abdomen. Dr. Carpenter concludes that it is not an ovipositor but rathor of the nature of a respiratory tube such as is found in water bugs of the recent family Nepida. This contention presupposes that tho insect was aquatic, but there appears to be no indication of any modifica. tion of the rest of the body from an aquatic environ. ment, a feature shown in the recent family Nepidx.

The remainder of the paper deals with the Psocoptera, Protelytroptera and Protoperlaria.

A. D. I.

\section{INVENTIONS AND PATENTS IN GREAT BRITAIN*}

\begin{abstract}
$\mathrm{T}$
HE fifty-sixth report of tho Comptroller-General of Patents, Designs and Trade Marks for 1938, records a further increase in the number of patents, applications having increased from 36,266 in 1937 to 37,973 in 1938 , with increases in the number of provisional and complete specifications from 21,745 and 22,215 , respectively, to 26,696 and 23,098 . In regard to the trend of inventions, the synthetic

* Patents, Designs and Trade Marks. Fifty-sixth Report of the Comptroller-General of Patents, Designs and Trade Marks, with Appendices, for the Year 1935. Pp. 26. (London: II.M. Stationery Office, 1939.) $6 d$. net.
\end{abstract}

production of artificial wool and rubber, the latter by the polymerization of diolefines and halogenated diolefines, continues to be prominent. New devolopments in the very active field of synthetic resins are the use of polyamide resins for making artificial yarn and the use of resins in water purification by ionic exchange. Antioxidants or stabilizers for rubber, oils, fats, soaps, aldehydes and light-sensitive substances are much in evidence. Applications relating to azo and vat dyes decreased in number, but the develop. ment of long-chain polymethino dyes for use as photographic sensitizers is actively sustained. 
The manufacture of glass fibres of extreme fineness and the use of short-path high-vacuum distillation for the concentration of vitamins have received attention, as well as directional wireless systems in relation to the navigation and blind landing of aircraft. Notable developments with electron microscopes relates to the magnetic lens systems, the arrangements for inserting the object under examination and the use of a fine scanning beam in place of a fixed electron beam. Methods of giving air-raid signals over electric power networks are being explored, and another interesting dovelopment is concerned with the speedy testing of watches, for accurate time-keeping, by electric means. A notablo feature has been the production of vehicle bodies and aircraft fuselages and girders from synthetic resins. Mechanical remoto-control systems are being devised to free the floors of motor-vehicles from obstruction by control levers, while another field of activity has been in gyroscopic instruments for indicating the course and altitude of flight of aircraft and in the automatic supervision, by means of magnetic compasses, of courseindicating gyroscopes so as to eliminato wandering.

Applications for designs and registered designs both decreased in number compared with 1937, but registered trade marks increased.

\section{GEOGRAPHICAL DISTRIBUTION OF THE COWRIES}

\begin{abstract}
IN the study of the geographical distribution of the I littoral marine fauna, the Mollusca claim special attention, since the activities of collectors have provided far more abundant data regarding them than are available for any other group of marine animals. More especially is this the case with such groups as the large and handsome tropical cowries and cones which have been favourites of the dilettanti for two centuries at least. It is true that a great deal of the older work on them is without any scientific value; endless lists of 'varietal' names have been given to individual abnormalities, environmental modifications, and stages of growth, while localities have been vaguely or incorrectly recorded. Nevertheless, it has long been obvious that a great amount of valuable material was awaiting scrutiny by modern methods.

This has now been done for the cowries by Dr.F.A. Schilder and Dr. M. Schilder in a "Prodrome of a Monograph on living Cypræidæ" (Proc. Malacol. Soc., 23 , Pts. 3 and $4 ; 1938-39$ ), in which a revision of the whole family is given, together with a detailed analysis of the distribution of the species and subspecies composing it. 'The material studied by the authors comprised more than 60,000 shells, in some eighty public and private collections in Europe. They recognize 165 species, nearly all of which are further subdivided, each into two or more geographical races or sub-races. The races and sub-races are treated
\end{abstract}

together for nomenclatorial purposes as sub-species, and they "can be recognized at least by the sum of several variable characters of the adult shells and by the fact that each race has usually its own centre of distribution where it is relatively moro frequent than at the periphery". The species and races are further grouped into units of higher order designated 'superspecies', which are equivalent to the Rassenkreise of Rensch, and are defined as "the sum of the allied species and sub-species inhabiting a mostly continuous region and geographically separate from each other".

The authors' conception of a super-species is not very easy to grasp, and it must bo said that their exposition is not everywhere a model of clarity. For example, the statement that "in some genera several evidently allied species inhabit the same region; they must each be treated as different superspecies" would seem difficult to reconcile with the definition just quoted. It can be so reconciled, but only to leave one in doubt whether the idea of super-species is worth very much after all.

Nevertheless, the monograph deserves careful study as perhaps the first attempt to apply on a large scale to marine animals those methods of geographical delimitation of races which have hitherto been applied almost exclusively to terrestrial and freshwater organisms.

IV. T. C.

\section{THE BREEDING OF OYSTERS*}

\begin{abstract}
GXPERIMENTS on the breeding of oysters in large concrete tanks have been in progress at Conway, North Wales, since 1919. The ultimate aim of the work has been to provide a simple and efficient means of procuring the settlement of large crops of oysters in tanks, in the belief that such a method would prove of value to the oyster growers in replenishing their stocks. Mrr. Cole has already explained his methods in two previous papers: "Experiments in the Breeding of Oysters (Ostrea

* Fishery Investigations. Series II, 16, No. 4. "Further Experiments in the Breeding of Ossters (Ostrea edulis) in Tanks", by H. A. Stationery Office, 1939.)
\end{abstract}

edulis) in Tanks, with Special Reference to the Food of the Larva and the Spat" (Fishery Investigations, Series II, 15, No. 4, 1936) and "A System of Oyster Culture" ( $J$. du Conseil, 13, No. 2, 1938). It is now believed that this aim has been realized and that spatfalls of commercial magnitude may be obtained regularly in the Conway tanks.

This work is of great interest and importance and based upon years of labour, early experiments having been mado at Conway by Dr. R. W. Dodgson and Mr. H. P. Sherwood.

The main plan is to enrich one large tank gradually by the addition of finely ground crab meat, 